\title{
Study on Water Level and Salinity Characteristics of Nakdong River Estuary Area by Discharge Variations at Changnyeong-Haman Weir(1)
}

\author{
Tae-Woo Kim*, Hyun-Soo Yang ${ }^{* *}$, Byeong-Woo Park ${ }^{* * *}$ and Jong-Sung Yoon ${ }^{*}$ \\ "Department of Civil and Urban Enoineering, Inje University, Gimhae, Korea \\ ${ }^{* *}$ Sekwang Engineering Consultants Co., Ltd. Coastal and Harbor and Disaster Prevention Research Institute, Seoul, Korea \\ ${ }^{* * *}$ Korea Water Resources Corporation, K-water, Daegu, Korea

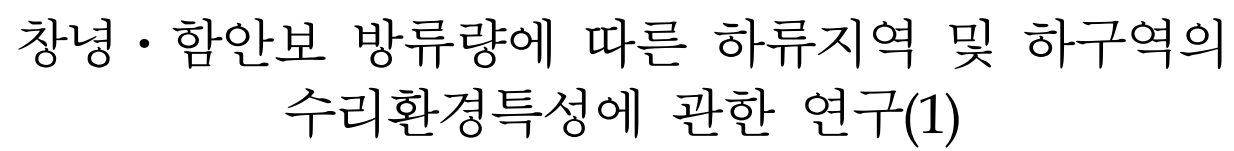
김태우 $*$ 양현수 ${ }^{* *}$ 박병우 ${ }^{* *} \cdot$ 윤종성(
"인제대학교 토목공학과
**세광엔지니어링 해안항만 방재연구소
한국수자원공사 낙동강통합물관리센터

KEY WORDS: Nakdong river estuary 낙동강 하구, Weir 보, Discharge 방류, Salinity 염분, Saline Wedge 염수쐐기

\begin{abstract}
The present study analyzed the variation factors in inducing a salinity change using the existing observation network in the section between the Nakdong River Estuary Barrage and Changnyeong-Haman Weir, and also examined the seasonal changes in precipitation, salinity, and discharge. Furthermore, this study analyzed the causes of a salinity increase by collecting observational data during a period when abnormal salinity occurred, and further investigated the salinity transfer time in a section of approximately $5.3 \mathrm{~km}$ from the Nakdong River Estuary Barrage to Nakdong River Bridge to understand the behavioral characteristics of the salinity moving upstream. The study results would make it possible to control the increase in salinity and block salt water from moving upstream by understanding the salinity variation characteristics according to the discharge amount. This will provide stability in collecting water from various residential, agricultural, and industrial sources through water intake facilities scattered near the Nakdong River Estuary Barrage.
\end{abstract}

\section{1. 서 론}

낙동강은 한반도 동남부에 위치하며 우리나라 제2의 유역이 다. 낙동강은 옛날부터 내륙지방 교통의 동맥으로서 조운에 이 용되었으며, 그에 따라 낙동강 연안에 선착장이 번창하며 여러 도시들이 형성되었다. 낙동강 하구에는 1987년 11월에 준공된 낙동강 하굿둑이 위치해 있으며, 하굿둑의 완공으로 바닷물의 역류 현상을 막아 낙동강 하류지역 시민의 식수를 비롯한 농업 및 공업용수의 수원지로 이용되어 왔다. 하지만 하굿둑 수문 운 영 상황 및 하굿둑 내·외 수위차, 방류량 등의 요인으로 인하 여 하굿둑을 통한 염수의 소상 현상이 간혹 발생되고 있다.

낙동강 하굿둑 창녕 - 함안보 구간에는 매리취수장, 강서 취 수장, 양산 신도시 취수장, 물금취수장, 원동취수장 및 부산시
공업용 취수장 등 여러 취수장이 위치해 있으며 현재 김해, 양 산 및 부산시민의 식수 공급원 및 농·공업용수로 이용되고 있 다. 염수가 소상하여 취수장 인근으로 확산될 경우 취수원에 문 제가 발생하게 되어 식수의 수질 기준인 $0.5 \mathrm{psu}$ 를 초과할 경우 생활용수의 취수에 문제가 발생되며, 김해지역의 농지 $150 \mathrm{~km}^{2}$ 중 약 $60 \mathrm{~km}^{2}$ 에 달하는 면적에 염해를 입힐 우려가 있다. 또한, 공업용수의 취수 한계농도 $0.3 \mathrm{psu}$ 를 초과할 경우 취수가 중단되 어 주변에 산재한 공업지역에 피해가 발생하게 된다. 따라서 창 녕 - 함안보에서 방류를 통하여 염분도의 상승을 제어할 필요가 있다.

그러나 4대강 사업이후에 낙동강 하구에서의 수문 운영 및 방류량에 따른 염분도 특성에 대한 연구는 여러 가지 이유에 의해 거의 이루어지지 않은 실정이다.

Received 23 August 2018, revised 6 October 2018, accepted 18 October 2018

Corresponding author Jong-Sung Yoon: +82-55-320-3434, civyunjs@inje.ac.kr ORCID: http://orcid.org/0000-0002-2382-530X

(c) 2018, The Korean Society of Ocean Engineers

This is an open access article distributed under the terms of the creative commons attribution non-commercial license (http://creativecommons.org/licenses/by-nc/3.0) which permits unrestricted non-commercial use, distribution, and reproduction in any medium, provided the original work is properly cited. 
낙동강 하굿둑 상류부의 염분을 제어하기 위하여 담수의 순 간 방류량이 증가할 경우 낙동강 하구 하류 해역의 표층 염분 은 최소 $19.593 \%$ 까지 감소하며(Yoon et al., 2008), 2014년에 방 영된 $\mathrm{KNN}$ 뉴스에 의하면 하굿둑 운영으로 인한 방류영향 때문 에 평소 염분 농도보다 약 $25 \%$ 이하로 떨어져 인근 하구 해역 에 위치한 김양식장에서 김 종묘의 집단폐사 등의 피해가 발생 한 사례가 있다(KNN, 2018). 또한, 수문 개방이 현실화 될 경우 에 해역으로 유입되는 담수 및 부유사의 확산, 오염물질의 침 퇴적 등으로 인해 하구 생태 환경과 해역지형의 변화가 나타날 것으로 판단된다.

염수소상에 의한 상류부의 취수안전성 문제 및 하천 방류에 따 른 하류 해역의 피해를 최소화하기 위한 대책 마련을 위해서는 낙동강 하굿둑 상류부의 염수의 거동 및 하구역의 수질 환경변화 에 대한 특성을 파악하는 것이 매우 중요한 것으로 판단된다. 따라 서 기존 관측 자료의 분석을 통해 방류량에 따른 염분의 거동 특성 을 파악할 필요가 있는 것으로 사료되며, 본 연구에서 창녕 - 함안 보 방류량, 하굿둑 수위, 풍속 및 염분도 등 기존 관측 자료를 분석 하여 염분의 계절별 변동 특성을 파악하고자 한다.

\section{2. 연구의 필요성 및 분석 방법}

낙동강 하굿둑 하류의 조위변동은 약 SMSL(Standard mean sea level) $-0.5 \sim 1.4 \mathrm{~m}$ 로 하루 2회 간 - 만조가 발생하는데 하굿둑 상류 수위는 Fig. 1과 같이 SMSL $+0.69 \mathrm{~m} 1.19 \mathrm{~m}$ 에서 운영하도 록 권장하고 있다. SMSL은 하굿둑에서의 평균해수면(Mean sea level, MSL)을 나타내는 것으로 부산항 인근의 하단, 명지지점 의 MSL보다 $0.18 \mathrm{~m}$ 낮다(K-water, 2006).

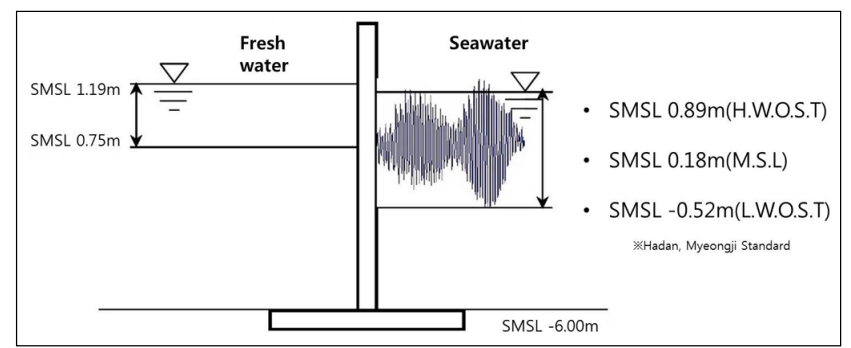

Fig. 1 Operation water level(Nakdong river estuary barrage)

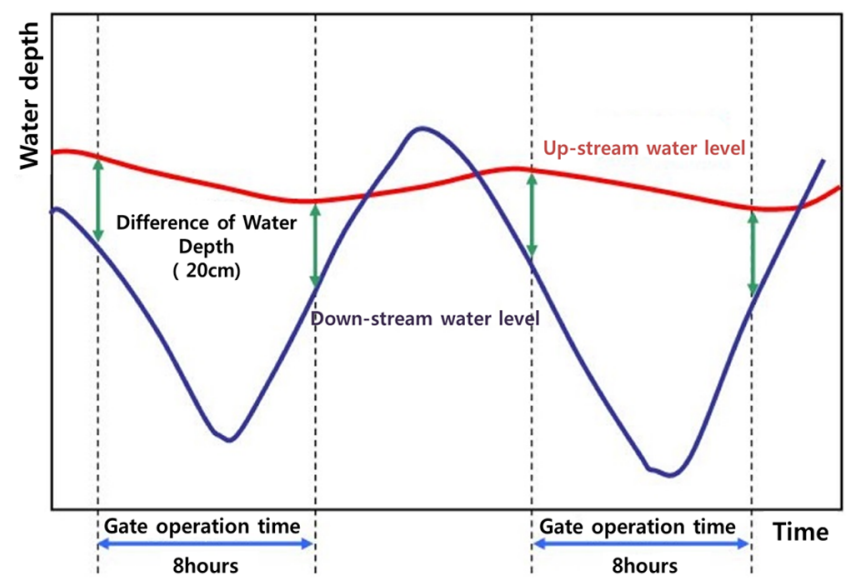

Fig. 2 Water gate operation by water level
하굿둑 운영의 주 목적은 앞서 언급한 바와 같이 상류 저수지 로 해수의 염분이 침투하는 것을 차단하여 식수 및 농·공업 용수를 공급하는데 있다. 수요자에게 필요한 원수를 안정적으 로 공급하기 위하여 Fig. 2와 같이 하굿둑의 상-하류 수위차가 $20 \mathrm{~cm}$ 이내일 경우 주배수문과 우안배수문을 폐쇄하여 염분도 상승을 제어하고 있다(K-water, 2008).

현재 낙동강 하굿둑에 관한 연구를 살펴보면 4대강 사업 이 후 하굿둑의 수문 운영 및 개방에 따른 염분확산에 관한 연구 는 전무한 실정이다.

더구나 낙동강의 재자연화 또는 기수역화를 위한 하굿둑 수 문의 개방에 대한 사회적 요구가 거센 작금의 현실을 감안 할 때, 낙동강 하굿둑 창녕 - 함안보 구간의 염분도의 변화 특성 에 대한 연구가 시급한 실정이다.

한편, 2016년 1월 낙동강 하굿둑에서 유입된 염수가 상류로 소상하여 공업용수의 취수가 중단된 사례가 있다. 따라서 기존 관측망의 염분도 변동 인자를 분석하여 염분도 상승의 원인을 파악할 필요가 있으며, 그 원인에 따른 대책 방안을 마련하여 취수 안정성을 확보해야 한다고 판단된다.

연구 방법으로 기존 관측망을 이용하여 계절별 염분도 변동 인자에 대한 상관관계 분석을 수행하였으며, 이상 염분발생의 원인 분석을 수행하였다. 또한, 하굿둑에서 침입한 염수가 상류 약 $5.3 \mathrm{~km}$ 에 위치한 낙동강교까지 소상한 것으로 나타난 시기의 관측데이터를 분석하여 염분의 도달시간 및 거동 특성을 분석 하였다.

\section{3. 계절에 따른 염분 변동 특성}

방류량에 따라 염수의 거동 형태가 정해지므로 방류량은 염분도 의 변동에 가장 큰 원인으로 판단된다. 2015년 1월 2017년 6월의 계절별 평균 방류량을 분석한 결과 춘계의 경우 약 $258.5 \mathrm{~m}^{3} / \mathrm{s}$, 하계 약 $300.9 \mathrm{~m}^{3} / \mathrm{s}$, 추계 약 $292.5 \mathrm{~m}^{3} / \mathrm{s}$, 동계 약 $125.9 \mathrm{~m}^{3} / \mathrm{s}$ 로 나타났다.

또한, 방류량과 밀접한 관계가 있는 강수량 자료를 위의 기간 과 동일하게 수집하여 분석하였다. 부산지역의 계절별 평균 강 수량은 춘계 약 $127.6 \mathrm{~mm} / \mathrm{hr}$, 하계 약 $124.7 \mathrm{~mm} / \mathrm{hr}$, 추계 약 $167.5 \mathrm{~mm} / \mathrm{hr}$, 동계 약 $50.7 \mathrm{~mm} / \mathrm{hr}$ 로 나타났다.

Table 1에 2015년 1월 2017년 6월의 계절별 평균 방류량 및 평균 강수량을 정리하여 나타내었다.

낙동강교 지점의 염분도 분석 결과 평수기의 경우 전 계절에 걸쳐 약 $0.3 \mathrm{psu}$ 이하로 나타났으며, 최대 $0.4 \mathrm{psu}$ 를 넘지 않는 것 으로 나타났다. 그러나 하굿둑 수문 운영 상황 및 하굿둑 내 외의 수위차, 창녕-함안보의 방류량 등에 따라 일시적으로 $0.8 \mathrm{psu}$ 를 초과하는 경우가 발생하는 것으로 나타났다.

Table 1 Discharge and Precipitation

\begin{tabular}{ccc}
\hline \hline Season & Discharge $\left[\mathrm{m}^{3} / \mathrm{s}\right]$ & Precipitation $[\mathrm{mm} / \mathrm{hr}]$ \\
\hline Spring & 258.5 & 127.6 \\
Summer & 300.9 & 124.7 \\
Fall & 292.5 & 167.5 \\
Winter & 125.9 & 50.7 \\
\hline
\end{tabular}




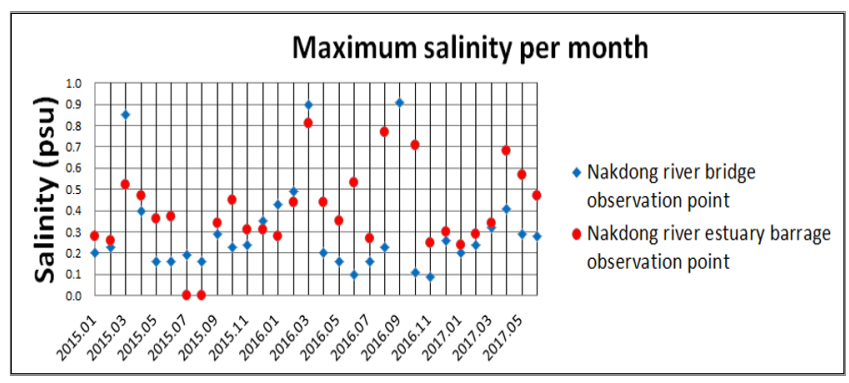

Fig. 3 Maximum salinity per month (2015.01-2017.06)

낙동강교 지점에서 춘계 염분도의 최댓값은 평균적으로 $0.41 \mathrm{psu}$ 로 관측되었으며, 하계, 추계 및 동계의 경우 각각 0.18 , $0.19,0.30 \mathrm{psu}$ 로 춘계 > 동계 > 추계 > 하계 순으로 나타났다.

Fig. 3 에 낙동강교 및 하굿둑의 월별 최대 염분도를 나타내었다.

\section{4. 관측 데이터 분석}

낙동강교 및 하굿둑의 염분 변동 특성을 파악하기 위해 방류 량, 하굿둑 수위, 풍속에 대하여 비교 - 분석을 수행하였다.

또한, 이상 염분이 발생한 시기의 데이터를 분석하여 나타내 었으며, 하굿둑을 통해 유입된 염분의 거동특성을 파악하기 위 하여 상류로 소상하거나 하류로 Flushing되는 염분의 전달시간 에 대하여 분석하였다.

\section{1 이상 염분발생 분석}

2015년 3월의 경우 낙동강교의 최대 염분도는 $0.85 \mathrm{psu}$, 하굿 둑의 최대 염분도는 $0.52 \mathrm{psu}$ 로 나타났다. 특이하게 낙동강교의 염분농도가 하굿둑보다 매우 높게 나타났다. 염분도 상승의 원 인을 분석한 결과, 수문부 하류 조위의 영향으로 수문부 상류 수위가 약 $0.31 \mathrm{~m}$ 상승한 것으로 나타났으며, 이 때 염분이 침투 한 것으로 판단된다. 하굿둑에서 유입된 염분은 점차 상류로 소 상하여 낙동강교 지점에서의 염분도가 하굿둑 염분도 보다 높 게 관측된 것으로 판단된다. 또한, 지속적인 바람의 영향으로 인하여 염수의 소상이 가중되었을 것으로 사료된다. 따라서 이 시기에 염분의 Flushing을 위해 창녕-함안보에서 최대 약 $930 \mathrm{~m}^{3} / \mathrm{s}$ 의 유량을 방류하여 염분도의 상승을 제어한 것으로 나 타났다.

Fig. 4에 2015년 3월의 관측 결과를 수위, 염분도, 방류량, 풍 속 순으로 나타내었다.

2016 년의 경우 1 월 20 일 16 시 하굿둑 상류 $10 \mathrm{~km}$ 지점에 위치 한 강서공업취수장에서 일시적으로 염분도가 공업용수의 한계 농도 $(0.3 \mathrm{psu})$ 를 초과하여 공업취수장의 취수중단 위기 상황이 발생하였다. 그 원인분석 결과 염분이 상승하기 며칠 전 하굿둑 운영특성(' 15 년 갑문운영 10 회, 주수문을 통한 대형선박 이동 4 회, 수문의 보수 및 보강 등)으로 인한 저층 염분침투 누적 및 2016 년 1 월 20 일 전에 $12 \mathrm{~m} / \mathrm{s}$ 를 초과하는 강한 북서풍의 작용으 로 인하여 염수 소상이 더욱 증가한 것으로 판단된다.

상류 댐-보에서 증가방류를 실시하고 하굿둑 집중 방류 2 회를 통해 1 시간 이내로 안정을 찾았으나, 낙동대교 지점의 저층 염 분은 $0.4 \mathrm{psu}$ 수준으로 남아 있는 것으로 나타났다. 취수중단 위

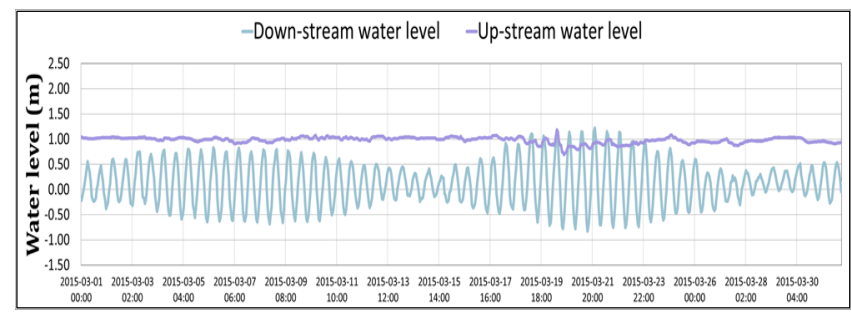

(a) Water level

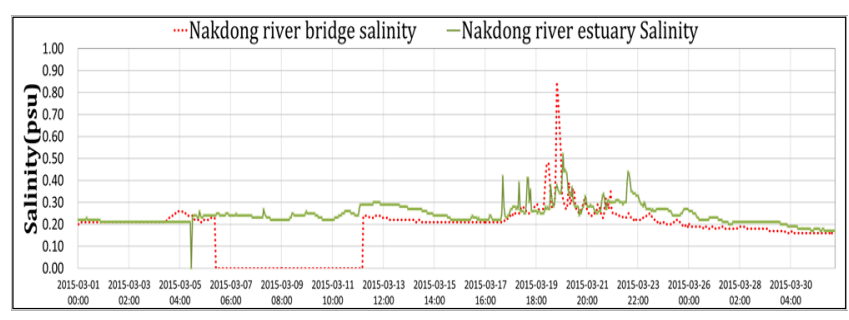

(b) Salinity

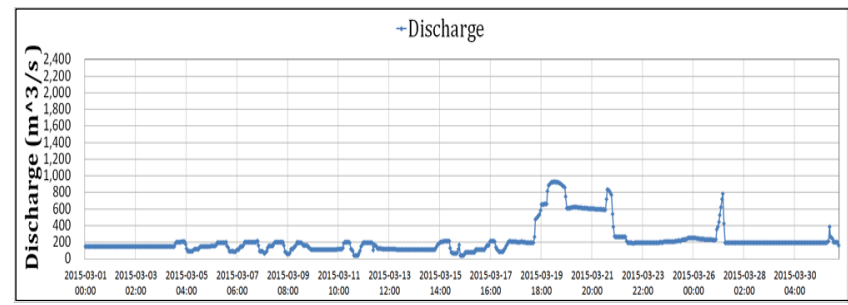

(c) Discharge

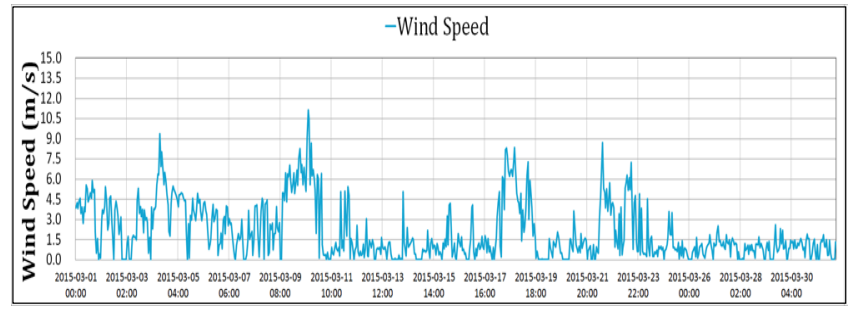

(d) Wind speed

Fig. 4 Water level, Salinity, Total discharge and wind speed observation data (2015.03)

기로 부터 2 시간 후 창녕-함안보의 방류량 확인 결과 약 $200 \mathrm{~m}^{3} / \mathrm{s}$ 수준으로 나타났으며, 적은 방류량으로 인하여 염분을 충분히 제어하지 못한 것으로 판단된다. 따라서 하굿둑 수문 개 방으로 인하여 발생하는 염수의 소상을 차단하기 위하여 창녕 - 함안보와 낙동강 하굿둑의 적절한 연계운영이 필요할 것으로 판단되며, 수문개방에 따른 구체적인 방류량 설정을 통하여 선 제적 대응이 필요할 것으로 판단된다.

Fig. 5에 2016년 1월의 관측 결과를 염분도, 바람 Stick diagram, 풍속 순으로 나타내었다.

2016년 3월의 경우 하굿둑과 낙동강교에서 염분농도가 각각 $0.81 \mathrm{psu}, 0.90 \mathrm{psu}$ 의 최대치까지 상승하였으며 최대 약 $1,020 \mathrm{~m}^{3} / \mathrm{s}$ 의 유량을 방류하여 염분도가 약 $0.3 \mathrm{psu}$ 이하로 감소하는 것으 로 나타났다. 염분도 상승의 원인을 분석한 결과, 염분도가 상 승하기 전 수문부 상류의 수위가 수문부 하류 조위의 영향으로 인하여 약 $0.23 \mathrm{~m}$ 증가하는 것으로 나타났으며, 이 후 하류 조위 


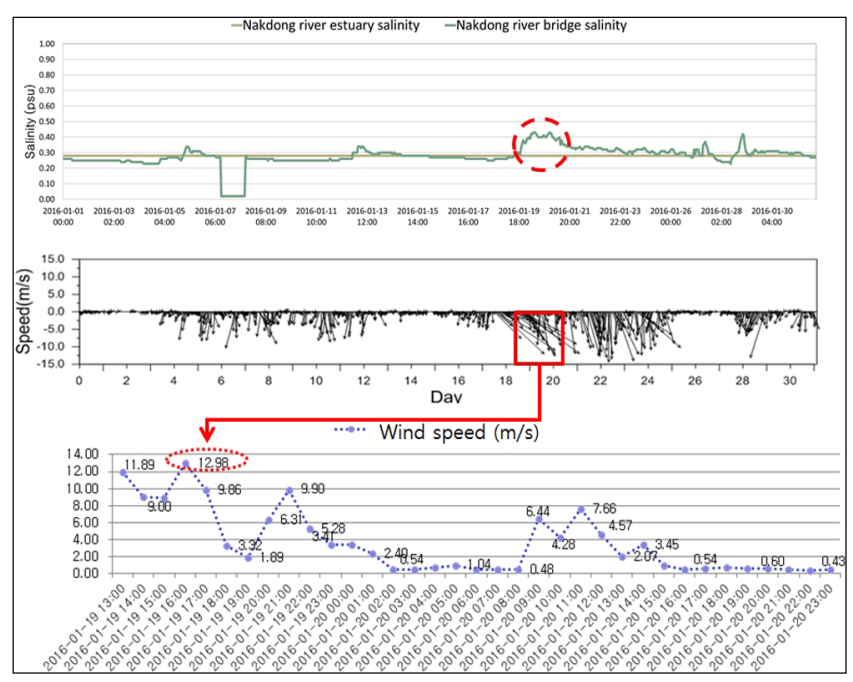

Fig. 5 Salinity observation data, Stick diagram, Wind speed graph (2016.01)

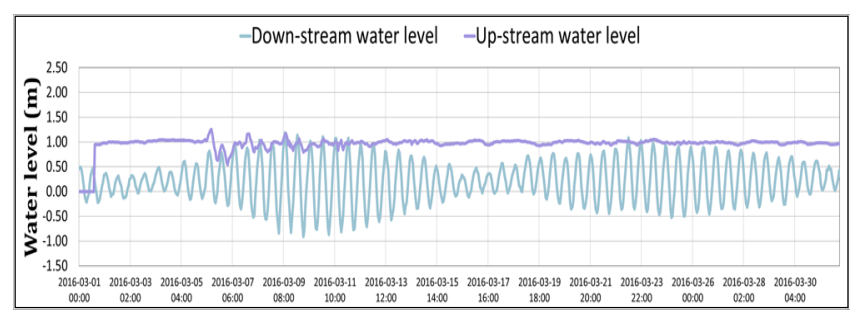

(a) Water level

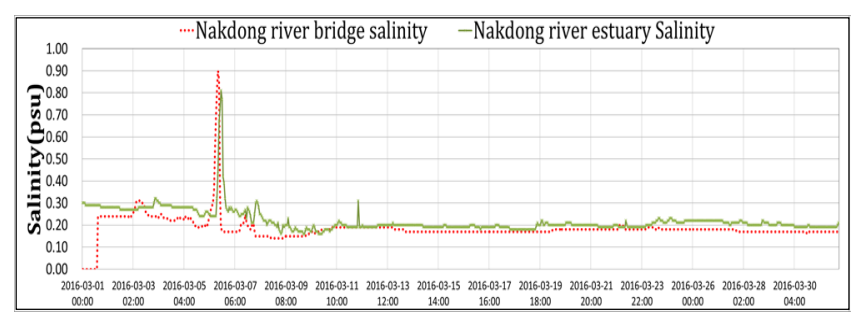

(b) Salinity

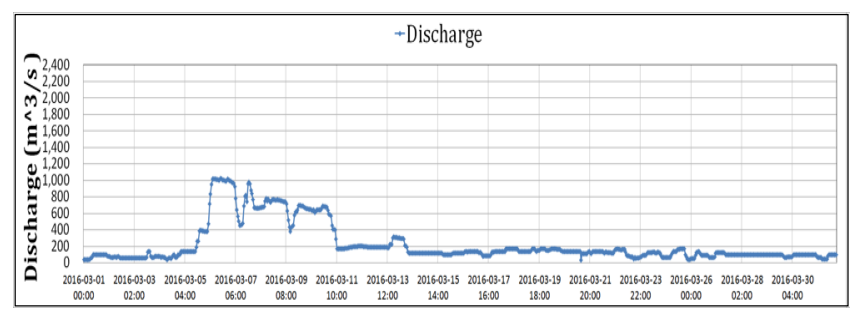

(c) Discharge

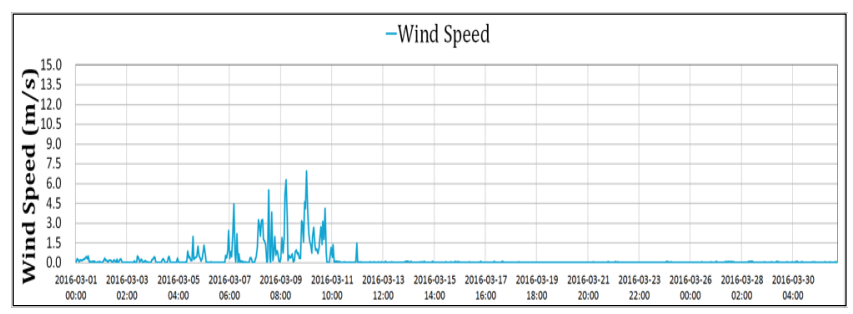

(d) Wind speed

Fig. 6 Water level, Salinity, Total discharge and wind speed observation data (2016.03)
를 따라 진동하는 것으로 나타났다. 따라서 이 때 하굿둑 하류 부의 염분이 유입된 것으로 판단된다.

Fig. 6에 2016년 3월의 관측 결과를 수위, 염분도, 방류량, 풍 속 순으로 나타내었다.

2016년 10월은 집중호우(부산지역 10월 5일 강수량 95mm)를 동반한 태풍‘차바’의 내습으로 인하여 하굿둑 상류 및 하류 수 위가 각각 $\mathrm{SMSL}(+) 1.87 \mathrm{~m}, \mathrm{SMSL}(+) 2.23 \mathrm{~m}$ 까지 상승하였다. 하 굿둑의 염분 관측치는 최대 $0.71 \mathrm{psu}$ 까지 상승하였으며, 수위 조 절 및 염분 제어를 위해 최대 약 $2,300 \mathrm{~m}^{3} / \mathrm{s}$ 의 유량이 방류된 것 으로 나타났다. 2016년 10월의 낙동강 기상국 풍속 데이터의 경 우 결측된 것으로 나타났다. 그러나 태풍의 강한 바람으로 인하 여 염분도 유입에 큰 영향을 주었을 것으로 판단된다. 또한, 태 풍 내습으로 인해 해측 수위 상승으로 수문부의 하류 수위가 상류 수위보다 $0.36 \mathrm{~m}$ 높아진 것으로 나타났다.

Fig. 7에 2016년 10월의 관측 결과를 수위, 염분도, 방류량, 풍 속 순으로 나타내었다.

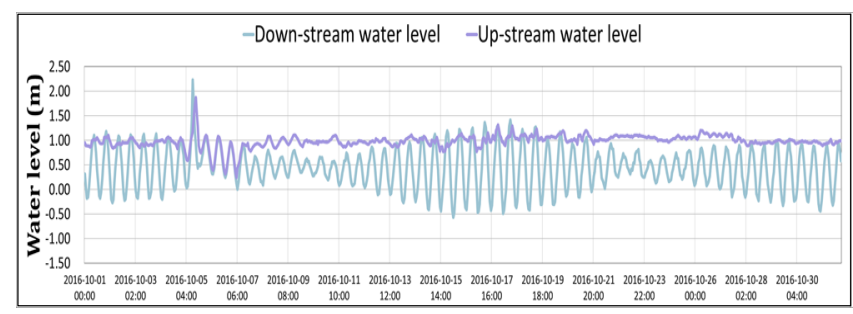

(a) Water level

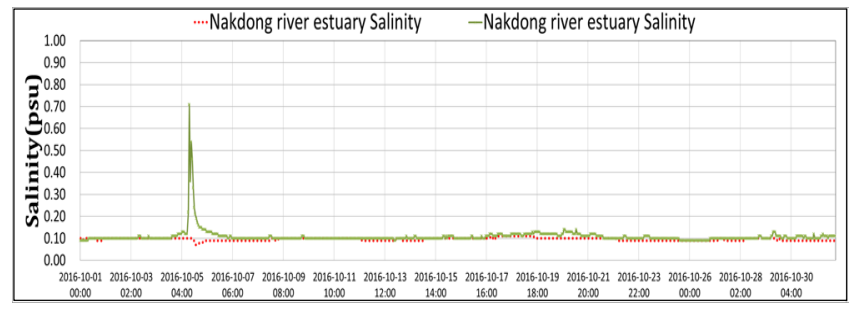

(b) Salinity

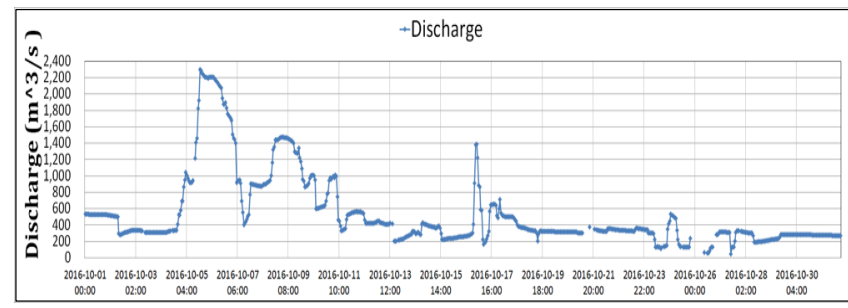

(c) Discharge

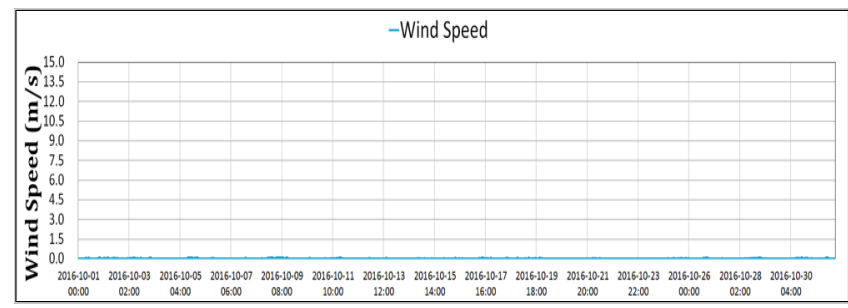

(d) Wind speed

Fig. 7 Water level, Salinity, Total discharge and wind speed observation data (2016.10) 


\section{2 염분 전달시간 검토}

낙동강 하굿둑을 통하여 침입한 염분은 수문부 하류 수위, 강 풍 등의 요인으로 인하여 점차 상류방향으로 소상하는 현상이 발생하게 된다. 따라서 염분의 거동특성 파악이 필요할 것으로 사료되어 2016년 9월의 관측 데이터를 이용하여 염분의 전달시 간 검토를 수행하였다.

2016년 9월 17일 6시 낙동강 하굿둑 지점의 염분도가 급격히 상승하기 시작하였으며, 3 시간 후 17 일 9시에 최대 염분도 12.21 psu 가 관측되었다. 염분도의 급격한 상승 에 대한 원인을 분석하기 위하여 수문부 수위의 관측 데이터를 분석한 결과, 하굿둑 지점의 염분도가 상승하기 1 시간 전 수문부 상류 수위가 SMSL. $(+) 0.86 \mathrm{~m}$ 에서 SMSL. (+) $1.36 \mathrm{~m}$ 까지 약 $0.5 \mathrm{~m}$ 상승한 후 수문부 하류 조위를 따라 진동하는 것으로 나타났다. 이 때 염분이 침입한 것으로 사료 되며, 낙동강 하굿둑 지점에서 최대 염분도가 관측된 시간으로부 터 5 시간 후 염분이 소상하여 낙동강교 지점에서 최대 염분도 $0.91 \mathrm{psu}$ 가 관측되었다. 낙동강교 지점까지 소상한 염분은 창녕 함안보에서 방류된 유량으로 Flushing되었으며, 낙동강교 지점에 서 후퇴한 염분으로 인하여 2시간 후 하굿둑 지점의 염분도가 일시 적으로 상승하는 경향을 보이는 것으로 나타났다.

방류량과 염분도의 관계를 분석한 결과, 하굿둑 지점의 염분 도가 상승하기 4 시간 전 약 $210 \mathrm{~m}^{3} / \mathrm{s}$ 의 기저유량으로부터 점차 유량을 증가시키며 방류를 실시한 것으로 나타났다. 그러나 하

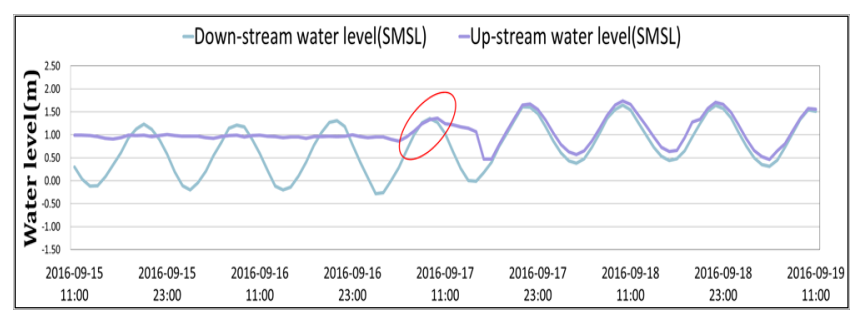

(a) Water level

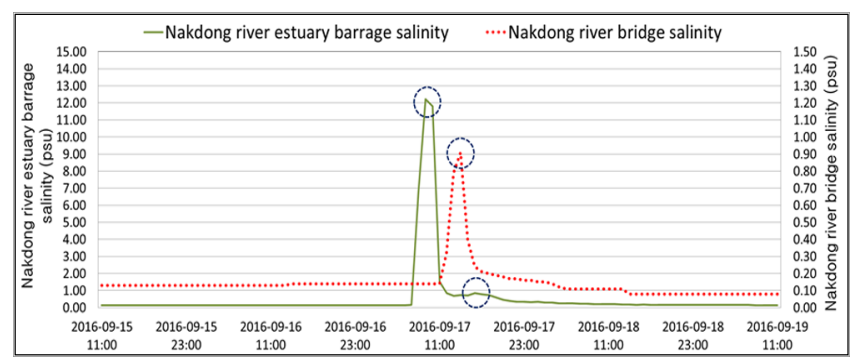

(b) Salinity

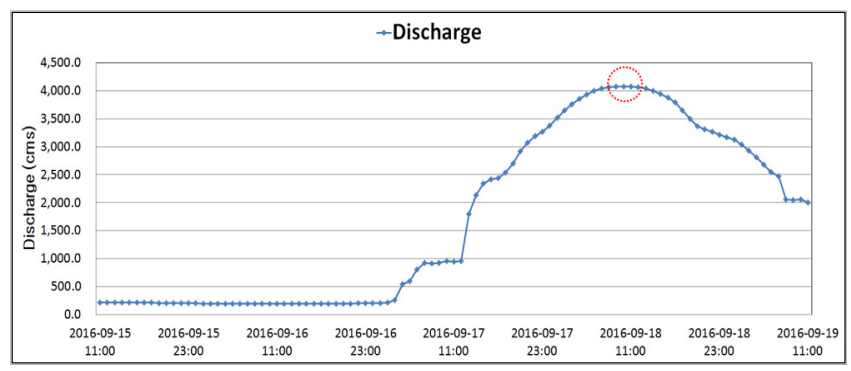

(c) Discharge

Fig. 8 Water level, Salinity and Total discharge (2016.09)
굿둑 지점에서 최대 염분도를 보인 17일 9시에 창녕·함안보의 방류량은 약 $920 \mathrm{~m}^{3} / \mathrm{s}$ 로, 염분 농도에 비하여 적은 방류량으로 인하여 염분의 소상을 완전히 제어하지 못한 것으로 사료된다. 그러나 지속적인 방류와 유량 증가를 통하여 염분을 제어하였 으며, 하굿둑 및 낙동강교 관측 지점의 염분도가 감소한 후에도 잔류염분의 완전한 Flushing을 위하여 계속해서 방류하여 9월 18 일 11 시 최대 약 $4,080 \mathrm{~m}^{3} / \mathrm{s}$ 의 유량을 방류한 것으로 나타났다. 2016년 9월의 수위, 염분도 및 방류량 관측데이터를 Fig. 8에 나타내었다.

\section{5. 결 론}

본 연구에서 기존 관측망의 데이터를 이용하여 낙동강 하굿 둑 창녕 - 함안보 구간의 염분 변동에 대하여 분석하였다.

염분도의 변동은 창녕 - 함안보의 방류량, 하굿둑의 수문 개 방, 수위, 바람 등 다양한 원인이 있는 것으로 나타났다. 관측 데이터를 분석한 결과 하굿둑을 통하여 일시적으로 침입한 염 수와 상류로 소상된 염분은 대부분 방류 유량만으로 제어가 가 능한 것으로 나타났다. 그러나 기수역 확보를 위한 장시간 수문 개방시 염분도 제어를 위해서는 일시적인 방류가 아닌 창녕 함안보에서 $900 \mathrm{~m}^{3} / \mathrm{s}$ 이상의 유량을 연속적으로 방류 할 필요가 있다(Choi et al., 2016). 그러나 $900 \mathrm{~m}^{3} / \mathrm{s}$ 이상의 유량을 연속적으 로 방류하는 것은 창녕·함안보의 관리수위(상류 : EL.(+)5m, 하류 : EL.(+)0.76m) 유지 등의 이유로 인하여 현실적으로 불가 능 할 것으로 판단된다. 또한, 창녕-함안보에서 유량을 방류하 고 있음에도 불구하고 낙동강 하굿둑을 통하여 침입한 염분은 단시간에 상류 약 $5.3 \mathrm{~km}$ 지점에 위치한 낙동강교 지점까지 소상 하는 것으로 나타났다. 따라서 강한 바람을 동반할 경우 대저수 문(낙동강 하굿둑 상류 약 $15 \mathrm{~km}$ 지점)까지 염분이 소상하여 인 근에 산재한 취수시설에 문제를 발생시킬 수 있을 것으로 사료 된다. 향후 낙동강 하구역 및 연안역의 염분거동 특성에 관한 수치모형 실험을 통한 연구를 진행하여 그 결과를 발표할 예정 이다.

따라서 향후 보다 상세한 장기적인 데이터 분석 및 수치모형 실험을 통하여 염분 변화 특성의 정확한 파악이 필요할 것으로 판단되며, 일시적인 염분도 상승 현상에 대한 보 및 수문의 연 계 운영 방안과의 관련성에 대하여 검토 및 분석이 필요할 것 으로 판단된다.

\section{후기}

본 연구는 2017년 한국연구재단의 이공분야기초연구사업 (NRF-2017R1D1A3B03033090)의 지원을 받아 수행된 연구결과 중 일부임을 밝히며, 연구비 지원에 감사드립니다.

\section{References}

Yoon, H.S., Park, S., Lee, I.C., Kim, H.T., 2008. Spatiotemporal Variations of Seawater Quality Due to the Inflow of Discharge from Nakdong River Barrage. Journal of the Korean Society 
for Marine Environmental Engineering, 11(2), 78-85.

KNN, 2018. KNN News. [Online] Available at: $<$ http://www. knn.co.kr/39044> [Accessed 4 Nov. 2014]

Korea Water Resources Corporation(K-water), 2006. Hydrologic and Environmental Survey for Management at Nakdong Estuary Barrage.

Korea Water Resources Corporation(K-water), 2008. The Study for Ecosystem Restoration in the Nakdong River Estuary Area. 